\title{
The Determination of $\alpha$-Amylase
}

\section{with 2-Chloro-4-nitrophenyl- $\beta$ - $D$-maltoheptaoside as Substrate: Comparison with other Methods}

\author{
By J. C. M. Hafkenscheid and M. Hessels \\ Laboratory for Clinical Chemistry, Department of Internal Medicine, St. Radboud Hospital, Nijmegen, \\ The Netherlands
}

(Received December 7, 1984/April 1, 1985)

Summary: The determination of $\alpha$-amylase with 2 -chloro-4-nitrophenyl- $\beta$ - $D$-maltoheptaoside as substrate was evaluated. The molar lineic absorbance of the liberated product, 2-chloro-4-nitrophenol, depends on the concentration of the protein present in the test. The catalytic activity concentrations obtained with human native sera, urines and commercial test sera were compared with activity concentrations determined using substrates with the same carbohydrate chain length. The analytical agreement is acceptable for human sera and urines.

The relative reaction rates measured with $\alpha$-amylase of various origins and 7 different substrates are presented. The advantages of the new test are discussed.

Bestimmung von $\alpha$-Amylase mit 2-Chlor-4-nitrophenyl- $\beta$-D-maltoheptaosid als Substrat: Ein Methodenvergleich

Zusammenfassung: Die Methode zur Bestimmung von $\alpha$-Amylase mit 2-Chlor-4-nitrophenyl- $\beta$ - $D$-maltoheptaosid als Substrat wurde evaluiert. Die molare lineare Absorbanz des freigesetzten 2-Chlor-4-nitrophenol hängt von der im Testansatz vorliegenden Proteinkonzentration ab. Mit dieser Methode und mit Methoden, die Substrate gleicher Kohlenhydrät-Kettenlänge verwenden, in frischem menschlichen Serum, Harn und kommerziell erhältlichen Testseren bestimmte katalytische Konzentrationen werden miteinander verglichen. Die analytișche Übereinstimmung ist für menschliche Seren und Harne annehmbar.

Die mit $\alpha$-Amylase untèrschiedlicher Herkunft und sieben verschiedenen Substraten gemessenen relativen Reaktionsgeschwindigkeiten werden mitgeteilt. Die Vorzüge des neuen Tests werden erörtert.

\section{Introduction}

The introduction of the chromogenic endpoint methods $(1,2)$ has given a new impetus to the determination of the activity concentration of $\alpha$-amylase (1,4- $\alpha-D$-glucan glucanohydrolase, EC 3.2.1.1). Other procedures and other substrates, such as a blocked starch molecule (3), maltotetraose $(4,5)$, maltoheptaose (6), 4-nitrophenylmaltoheptaoside (7), and a mixture of 4-nitrophenylmaltopentaoside and -hexaoside (8), have been introduced. The most recently developed substrate for the determination of $\alpha$-amylase is 2-chloro-4-nitrophenyl- $\beta$ - $D$-maltoheptaoside (9). The increase of the absorbance of 2-chloro-4-nitrophenol at $405 \mathrm{~nm}$ can be measured. The interesting advantage of this method is reported to be that the liberated product is insensitive to changes both in temperature and $\mathrm{pH}$ under assay conditions. In this communication we present a short evaluation of this method, together with a comparison with some other methods for the determination of the activity concentration of $\alpha$-amylase. 


\section{Materials and Methods}

All determinations were carricd out at $37^{\circ} \mathrm{C}$ on a spectrophotometer (Beckman; model 25).

The kits for the determination of $\alpha$-amylase with 2-chloro-4nitrophenylmaltoheptaoside were a gift of E. Merck Nederland B. V. Amsterdam, The Netherlands. The determinations and calculations were carried out exactly. according to the instructions of the manufacturer.

Other determinations were carried out with the following substrates: 4-nitrophenylmaltoheptaoside (Boehringer Mannheim GmbH, FRG); maltoheptaose (a gift from Boehringer Mannheim B. V., Almere, The Netherlands); maltotetraose (Instruchemie, Hilversum, The Netherlands); a mixture of 4-nitrophenylmaltopentaoside and -hexaoside (Testomar, Behringwerke AG Marburg, FRG); blocked starch molecule and Phadebas blue starch (both from Phadebas, Diagnostics AB, Uppsala, Sweden).

2-Chloro-4-nitrophenol was a gift from E. Merck Nederland B. V. Amsterdam, The Netherlands, and 4-nitrophenol was purchased from British Drug House (BDH), Brunschwig, Amsterdam, The Netherlands. All other chemicals were of reagent grade. Venous blood was sampled from normal volunteers and after clotting it was centrifuged. The determinations were carried out as soon as possible; otherwise the serum was stored at $-20^{\circ} \mathrm{C}$. Urine was collected as usually.

$\alpha$-Amylase from pig pancreas and $\alpha$-amylase from Bacillus subtilis were purchased from Boehringer Mannheim B. V., Almere, The Netherlands.

Human pancreatic $\alpha$-amylase was obtained from duodenal fluid (10) and human salivary $\alpha$-amylase from saliva. Enzyme preparations were diluted with a dilution fluid as described earlier (10). The reconstitution of the freeze dried sera was carried out as prescribed by the manufacturers.

All catalytic activity concentrations are expressed in $\mathrm{U} / \mathrm{l}$.

\section{Results and Discussion}

Table 1 shows the effect of increasing protein concentrations on the molar lineic absorbance of 2chloro-4-nitrophenol and 4-nitrophenol at two different buffer concentrations and two different $\mathrm{pH}$ values. These conditions were chosen according to

Tab. 1. Influence of albumin on the molar lineic absorbance of 2-chloro-4-nitrophenol and 4-nitrophenol at $405 \mathrm{~nm}$ and $37^{\circ} \mathrm{C}$.

\begin{tabular}{|c|c|c|c|c|}
\hline \multirow[b]{3}{*}{$\begin{array}{l}\text { Albumin } \\
(\mathrm{g} / \mathrm{l})\end{array}$} & \multicolumn{4}{|c|}{ Molar lineic absorbance $\left(\mathrm{m}^{2} \times \mathrm{mol}^{-1}\right)$} \\
\hline & $\begin{array}{l}\text { 2-Chloro-4- } \\
\text { nitrophenol }\end{array}$ & $\begin{array}{l}\text { 4-Nitro- } \\
\text { phenol }\end{array}$ & $\begin{array}{l}\text { 2-Chloro-4- } \\
\text { nitrophenol }\end{array}$ & $\begin{array}{l}\text { 4-Nitro- } \\
\text { phenol }\end{array}$ \\
\hline & \multicolumn{2}{|c|}{$\begin{array}{c}50 \mathrm{mmol} / \mathrm{l} \text { phosphate, } \\
\mathrm{pH} 6.8\end{array}$} & \multicolumn{2}{|c|}{$\begin{array}{c}100 \mathrm{mmol} / \mathrm{l} \text { phosphate, } \\
\mathrm{pH} 7.1\end{array}$} \\
\hline 0 & 1590 & 671 & 1730 & 993 \\
\hline 0.4 & 1540 & 674 & 1630 & 971 \\
\hline 0.8 & 1460 & 675 & 1600 & 943 \\
\hline 1.6 & 1430 & 678 & 1550 & 919 \\
\hline 3.2 & 1410 & 702 & 1530 & 851 \\
\hline
\end{tabular}

the specifications of the suppliers for 2-chloro-4nitrophenylmaltoheptaoside and 4-nitrophenylmaltoheptaoside respectively. Except for 4-nitrophenol in $50 \mathrm{mmol} / 1$ phosphate buffer at $\mathrm{pH} 6.8$, it is obvious that the molar lineic absorbance decreases with increasing protein concentration. At the highest concentration of albumin about $86 \%$ of the original value without albumin was found. Moreover, Jung \& Köhler (11) observed a decrease in molar lineic absorbance of 4-nitrophenol at $405 \mathrm{~nm}$ in diethanolamine buffer but not in $\mathrm{NaOH}$. The present studies show that results for the determination of $\alpha$ amylase with 2-chloro-4-nitrophenylmaltoheptaoside as substrate also depend on the protein concentration during the reaction. We used for our calculations a molar lineic absorbance value of $1660 \mathrm{~m}^{2} \cdot \mathrm{mol}^{-1}$ as indicated by the manufacturer. Henkel et al (9) have already pointed out that the molar lineic absorbance of 2-chloro-4-nitrophenol is independent of the temperature, in contrast to the data for 4-nitrophenol $(11,12)$.

We compared results for the measurement of $\alpha$-amylase using 2-chloro-4-nitrophenylmaltoheptaoside as substrate with those from the use of substrates of the same carbohydrate chain length as in 2-chloro-4nitrophenylmaltoheptaoside. The catalytic activity concentrations determined with 2-chloro-4-nitrophenylmaltoheptaoside as substrate were divided by the catalytic activity concentrations obtained with 4nitrophenylmaltoheptaoside as substrate. These quotients obtained for native human sera, urines, test sera and $\alpha$-amylase from pig pancreas, human pancreatic fluid, human saliva and Bacillus subtilis are given in figure 1. For native sera these quotients are equal to 1 , which means that both substrates, 2chloro-4-nitrophenylmaltoheptaoside and 4-nitrophenylmaltoheptaoside, are converted at the same rate by $\alpha$-amylase in human serum. The same holds for human urines. The quotients range from 0.64 to 1.52 for various test sera and are also quite different for the various $\alpha$-amylase preparations. A ratio of about 0.7 was obtained for 18 control sera. This ratio is equal to the ratio of 0.71 for $\alpha$-amylase from pig pancreas. So it is possible that these control sera have been enriched with $\alpha$-amylase from pig pancreas.

Figure 2 demonstrates the ratio obtained for the catalytic activity concentrations measured with 2chloro-4-nitrophenylmaltoheptaoside and maltoheptaose as substrate. The ratio for human native sera and urines is about 1.0 to 1.1. For the control sera, the ratio ranges from 0.13 to 1.28 , a difference of a factor 10. The ratio for $\alpha$-amylase from Bacillus subtilis is much higher than for the other $\alpha$-amylase preparations. 


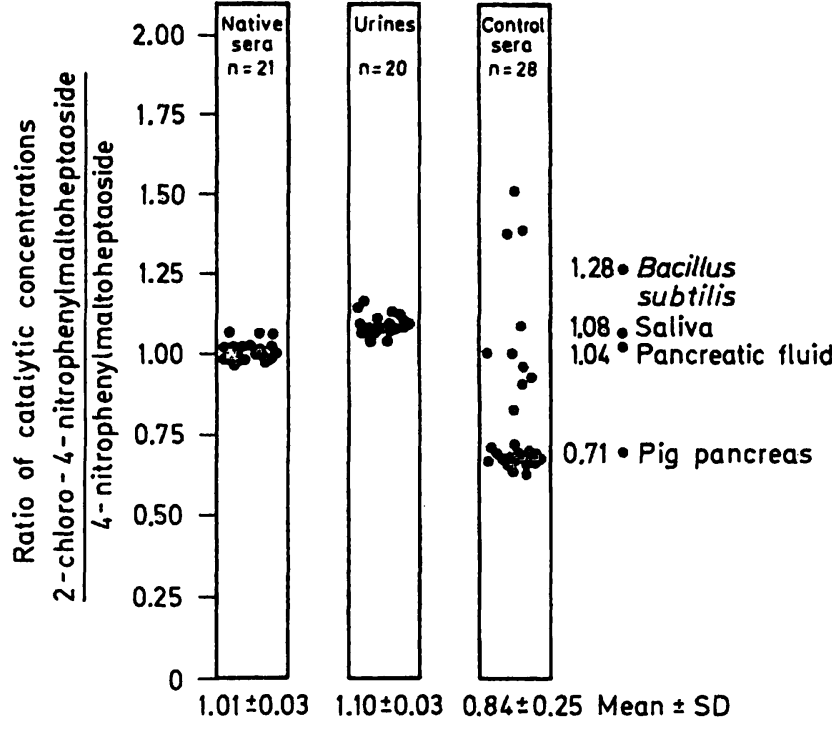

Fig. 1. Ratio of catalytic activity concentrations of $\alpha$-amylase obtained with 2-chloro-4-nitrophenylmaltoheptaoside and 4-nitrophenylmaltoheptaoside as substrates.

The ratio obtained for the catalytic activity concentrations measured with 4-nitrophenylmaltoheptaoside and maltoheptaose as substrate is shown in figure 3 . Again a ratio of about 1.0 was observed for human sera and urines and a very different ratio for control sera and the $\alpha$-amylase preparations.

Table 2 demonstrates the relative reaction rates of $\alpha$ amylase from Bacillus subtilis, human pancreatic fluid, human saliva and pig pancreas. The reaction rate for each of the preparations of $\alpha$-amylase obtained with the blue starch method was fixed at 1.00 , and the other reaction rates were calculated as fraction of the value. The lowest reaction rate for all $\alpha$-amylases tested was obtained with maltotetraose as the substrate; values varied from 0.00005 for $\alpha$-amylase from Bacillus subtilis to 0.221 for the enzyme from human saliva. An increase of the carbohydrate

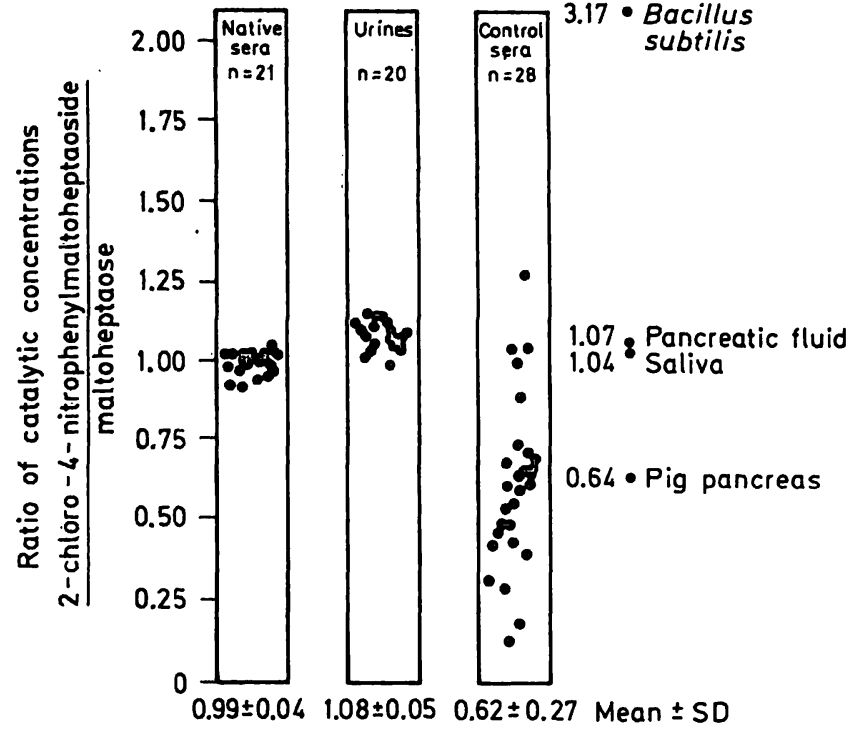

Fig. 2. Ratio of catalytic activity concentrations of $\alpha$-amylase obtained with 2-chloro-4-nitrophenylmaltoheptaoside and maltoheptaose as substrates.

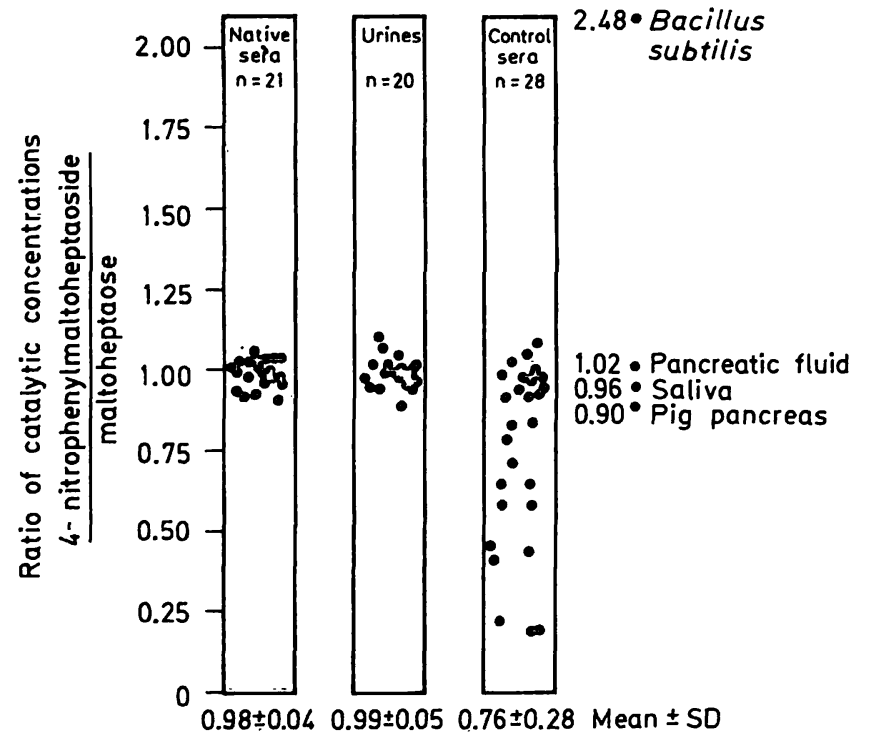

Fig. 3. Ratio of catalytic activity concentrations of $\alpha$-amylase obtained with 4-nitrophenylmaltoheptaoside and maltoheptaose as substrates.

Tab. 2. Relative reaction rates of the determination reaction of $\alpha$-amylase carried out with different substrates. The catalytic activity concentrations were expressed in $U / 1$ and afterwards the blue starch method was set at 1.000 .

$\alpha$-Amylase from

$\begin{array}{lllll}\begin{array}{l}\text { Bacillus } \\ \text { subtilis }\end{array} & \begin{array}{l}\text { Human } \\ \text { pancreatic } \\ \text { fluid }\end{array} & \begin{array}{l}\text { Human } \\ \text { saliva }\end{array} & \begin{array}{l}\text { Pig } \\ \text { pancreas }\end{array} & \frac{\text { Human pancreatic fluid }}{\text { Human saliva }}\end{array}$

\begin{tabular}{llllll}
\hline Substrate & & & & & \\
Maltotetraose & 0.00005 & 0.154 & 0.221 & 0.114 & 0.70 \\
4-Nitrophenylmaltopentaoside/-maltohexaoside & 0.00081 & 0.199 & 0.278 & 0.667 & 0.72 \\
Maltoheptaose & 0.036 & 0.615 & 0.706 & 1.618 & 0.87 \\
4-Nitrophenylmaltoheptaoside & 0.095 & 0.612 & 0.722 & 1.529 & 0.85 \\
2-Chloro-4-nitrophenylmaltoheptaoside & 0.123 & 0.600 & 0.674 & 1.040 & 0.89 \\
Blocked starch & 0.307 & 1.178 & 1.077 & 1.417 & 1.09 \\
Blue starch & 1.000 & 1.000 & 1.000 & 1.000 & 1.00 \\
\hline
\end{tabular}


chain of the substrate increases the reaction rate of $\alpha$-amylase from Bacillus subtilis. The highest reaction rate for the bacterial $\alpha$-amylase was obtained when blue starch was the substrate, this compound being the largest molecule of all substrates tested.

When $\alpha$-amylase of human origin was tested, the reaction rate with maltotetraose or a mixture of 4nitrophenylmaltopentaoside and -hexaoside as substrate, was obviously low. Moreover, the reaction rate was about the same with both substrates, in contrast to $\alpha$-amylase from Bacillus subtilis or from pig pancreas. An increase of the carbohydrate chain to 7 glucose units (maltoheptaose, 4-nitrophenylmaltoheptaoside or 2-chloro-4-nitrophenylmaltoheptaoside) increases the reaction rate, while the differences between these 3 substrates are very low. So it seems that the presence of 4-nitrophenol or 2chloro-4-nitrophenol in 4-nitrophenylmaltoheptaoside or 2-chloro-4-nitrophenylmaltoheptaoside does not influence the reaction rate of either of these human $\alpha$-amylases. The highest relative reaction rates were obtained when the blocked starch or the blue starch molecule was used as substrate. Again the reaction rates are about the same for both human $\alpha$ amylases, in contrast to bacterial or pig $\alpha$-amylase. As far as $\alpha$-amylase from pig pancreas is concerned the lowest reaction rate was again obtained with maltotetraose as substrate. The reaction rate was enhanced by increasing the carbohydrate chain of the substrate. There was a difference between the relative reaction rates when the 3 substrates maltoheptaose, 4-nitrophenylmaltoheptaoside or 2-chloro-4-nitrophenylmaltoheptaoside were used, the reaction rate being much lower for 2-chloro-4-nitrophenylmaltoheptaoside. The highest relative reaction rate was observed when blocked starch, maltoheptaose or 4-nitrophenylmaltoheptaoside served as the substrates. Apparently an entity of 7 to 9 molecules of glucose is the most suitable substrate for $\alpha$-amylase from pig pancreas, except when 2-chloro-4-nitrophenylmaltoheptaoside is used as substrate. It may be that the additionally introduced chlorine atom has some inhibitory influence on the catalytic activity of pig pancreatic $\alpha$-amylase, or the active center of the enzyme is different from that of human $\alpha$-amylase.
From the ratio, pancreatic to salivary $\alpha$-amylase, it can be concluded that an increase of the carbohydrate chain of the substrate favours the action of the pancreatic isoenzyme. These results are in agreement with those of Meier et al. (13), Sampson et al. (14) and Lorentz (15). Apparently $\alpha_{\text {-a }}$ amylase attacks not only different substrates in a different way, but also one substrate can be attacked in various ways by $\alpha$ amylase of different origin.

Generally it can be concluded that this new test for the determination of $\alpha$-amylase is good, practical and reliable as far as the determination of $\alpha$-amylase from human serum and urine is concerned. The test is $\mathrm{pH}$-independent in the normal measuring range (in contrast to the kit with 4-nitrophenylmaltoheptaoside as substrate), and it is also temperature independent, as described earlier (9). The assay is influenced by the protein concentration. The molar lineic absorbance depends on the reaction conditions and systematic errors of about $10 \%$ are present when no allowance is made for the influence of the reaction conditions. The test with 2-chloro-4-nitrophenylmaltoheptaoside as substrate is more sensitive than the test with 4nitrophenylmaltoheptaoside, and it needs less sample volume. The substrate is completely comparable with other substrates having the same length of the carbohydrate chain, except when pig pancreatic $\alpha$-amylase is the enzyme to be measured.

Lorentz (16) has formulated four essentials for the basis of a recommended method for $\alpha$-amylase measurement. In our view,, 2 -chloro-4-nitrophenylmaltoheptaoside fulfils most of the essentials, except for the fact that a lag phase is present at the start of the reaction.

\section{Acknowledgement}

The authors wish to thank E. Merck Nederland B. V., Amsterdam, The Netherlands for a generous gift of the test kits and Boehringer Mannheim B. V., Almere, The Netherlands, for the test kit with maltoheptaose as substrate. 


\section{References}

1. Ceska, M., Birath, K. \& Brown, B. (1969) Clin. Chim. Acta 26, 437-444.

2. Ceska, M., Brown, B. \& Birath, K. (1969) Clin. Chim. Acta 26, 445-453.

3. Marshall, J. J., lodice, A. P. \& Whelan, W. J. (1977) Clin. Chim. Acta 76, 277-283.

4. Pierre, K. J., Tung, K. K. \& Nadj, M. (1976) Clin. Chem. 22, 1219.

5. Alexander Jr., R. L. (1977) Clin. Chem. 23, 1369-1370.

6. Schiwara, H. W. (1972) Z. Klin. Chem. Klin. Biochem. 10, $12-16$.

7. Kaufman, R. A., Dunka Jr., L. J. \& Hall, L. M. (1980) Clin. Chem. 26, 1018.

8. McCroskey, R., Chang, T., David, H. \& Winn, E. (1982) Clin. Chem. 28, 1787-1791.

9. Henkel, E., Morich, S. \& Henkel, R. (1984) J. Clin. Chem. Clin. Biochem. 22, 489-495.
10. Hafkenscheid, J. C. M., Hessels, M. \& van der Hoek, E. W. (1983) J. Clin. Chem. Clin. Biochem. 21, 167-174.

11. Jung, K. \& Köhler, A. (1980) Clin. Chim. Acta 101, 1-4.

12. Bowers Jr., G. N., McComb, R. B., Christensen, R. G. \& Schaffer, R. (1980) Clin. Chem. 26, 724-729.

13. Meier, H., Henkel, E. \& Dankert, H. (1979) J. Clin. Chem. Clin. Biochem. 17, 709-716.

14. Sampson, E. J., Duncan, P. H., Fast, D. M., Whitner, V. S., McKneally, S. S., Baird, M. A., MacNeil, M. L. \& Bayse, D. D. (1981) Clin. Chem. 27, 714-720.

15. Lorentz, K. (1983) J. Clin. Chem. Clin. Biochem. 21, $463-471$.

16. Lorentz, K. (1979) J. Clin. Chem. Clin. Biochem. 17, $499-504$.

Dr. J. C. M. Hafkenscheid Laboratory for Clinical Chemistry Department of Internal Medicine St. Radboud Hospital University of Nijmegen P.O. Box 9101

NL-6500 HB Nijmegen 
